\title{
GEOLOGI BATUBARA DAERAH BINUNGAN KECAMATAN SAMBALIUNG KABUPATEN BERAU PROVINSI KALIMANTAN TIMUR
}

\author{
AYU ANDINI ${ }^{1}$, YAN RIZAL $^{2}$ \\ 1. Program Studi Teknik Geologi Universitas Jenderal Soedirman Fakultas Sains dan Teknik Jl. Mayjen \\ Sungkono KM 5 Blater Purbalingga 53371 Telp/Fax. (0281) 6596700 \\ 2. Program Studi Teknik Geologi, FITB, Institut Teknologi Bandung, Jalan Ganesa 10 Bandung, 40132 \\ Email:yan@gl.itb.ac.id
}

\begin{abstract}
Sari - Lokasi penelitian berada di daerah Binungan kawasan PT. Berau Coal yang mencakup area $\pm 32 \mathrm{~km}^{2}$, yang secara administratif termasuk dalam wilayah Desa Binungan, Kecamatan Sambaliung, Kabupaten Berau, Provinsi Kalimantan Timur. Secara fisiografis daerah telitian termasuk dalam Sub-Cekungan Berau dari Cekungan Tarakan. Stratigrafi daerah penelitian dari tua ke muda adalah Satuan Batupasir, Satuan Batupasir-Batulempung, Satuan Batupasir Konglomeratan yang berumur Miosen Tengah sampai Miosen Akhir dan Satuan Endapan Alluvial yang berumur Resen. Struktur geologi yang berkembang didaerah penelitan yaitu sesar turun dan sesar geser kiri yang diinterpretasikan dari korelasi bawah permukaan. Korelasi lapisan batubara dilakukan dari karakteristik fisik masingmasing lapisan batubara berdasarkan data e-log dengan menggunakan gamma ray, long density dan short density. Jumlah lapisan batubara yang berada di daerah Binungan ialah sebanyak 43 lapisan dengan 23 lapisan batubara yang menerus dan 20 lapisan batubara yang tidak menerus. Sumberdaya terukur batubara pada daerah penelitian yaitu sebesar 644.612.826,99 ton dan sumberdaya tertunjuk yaitu 1.592.733.025,26 ton, dengan persyaratan batas minimal ketebalan lapisan batubara yang dihitung menurut Standar Nasional Indonesia ialah 0,40 meter.
\end{abstract}

Kata kunci: batubara, korelasi, sumberdaya, Binungan

\begin{abstract}
The research area is located on PT. Berau Coal Binungan Area which has $\pm 32 \mathrm{~km}^{2}$. It is located in Binungan village, Sambaliung district, Berau regency, East Borneo. Physiography of research area is included of Berau Sub-Basin from Tarakan Basin. Stratigraphy in research area from old to young are Sandstone-Mudstone unit, interbedded Sandstone-Mudstone Unit, Conglomeratic Sandstone Unit, these are Midle-Late Miocene and also Recent Alluvial Deposition Unit. Coal seam correlation is applied from physical characteristic of each coal seam according to e-log by using gamma ray, long density and short density. Total coal seam in Binungan area is 3 seams, which 23 continous seams and 20 discontinous seams. Measured resource coal in research area is 644,612,826.99 ton and indicated coal is is 1,592,733,025.26 ton with condition minimal limit of coal seam thickness that calculated according SNI is $0.40 \mathrm{~m}$.
\end{abstract}

Keywords: coal, correlation, resources, Binungan

\section{PENDAHULUAN}

Batubara merupakan salah satu bahan bakar disamping minyak dan gas bumi dan panas bumi. Indonesia termasuk salah satu negara yang kaya dengan sumber daya energi dalam bentuk batubara. Batubara Indonesia umumnya tersingkap tidak jauh dari permukaan. Hal inilah yang menyebabkan pengusahaan batubara saat ini umumnya lebih banyak dilakukan dengan metode tambang terbuka (open pit). Penyebaran batubara disuatu tempat perlu dikaji sehingga dapat diketahui daerah yang prospek. Hasil analisis terhadap korelasi lapisan batubara kemudian dapat digunakan untuk mengevaluasi apakah sebuah kegiatan penambangan yang direncanakan layak untuk di tambang atau tidak yang sebelumnya dilakukan suatu perhitungan nilai keekonomisannya.

Penelitian geologi batubara di daerah penelitian ini dilakukan bertujuan untuk menentukan dan mengetahui kondisi geologi daerah penelitian secara permukaan maupun bawah permukaan, mengetahui tatanan geologi lokal berdasarkan geomorfologi, geologi 
struktur dan stratigrafi daerah penelitian, dapat mengkorelasikan lapisan batubara dari karakteristik fisik masing-masing lapisan batubara berdasarkan data logging (e-log), mengetahui kondisi bawah permukaan dan arah penyebaran lapisan batubara di daerah Binungan dan mengetahui sumberdaya batubara di daerah Binungan.

Lokasi penelitian berada di daerah Binungan PT. Berau Coal yang mencakup area $\pm 32 \mathrm{~km}^{2}$ yang secara administratif termasuk dalam wilayah Desa Binungan, Kecamatan Sambaliung, Kabupaten Berau, Provinsi Kalimantan Timur (Gambar 1). Daerah penelitian masuk dalam peta lembar geologi Muaralasan, Kalimantan, tahun 1995, yang diterbitkan oleh Pusat penelitian dan Pengembangan Geologi Bandung dengan skala $1: 250000$.

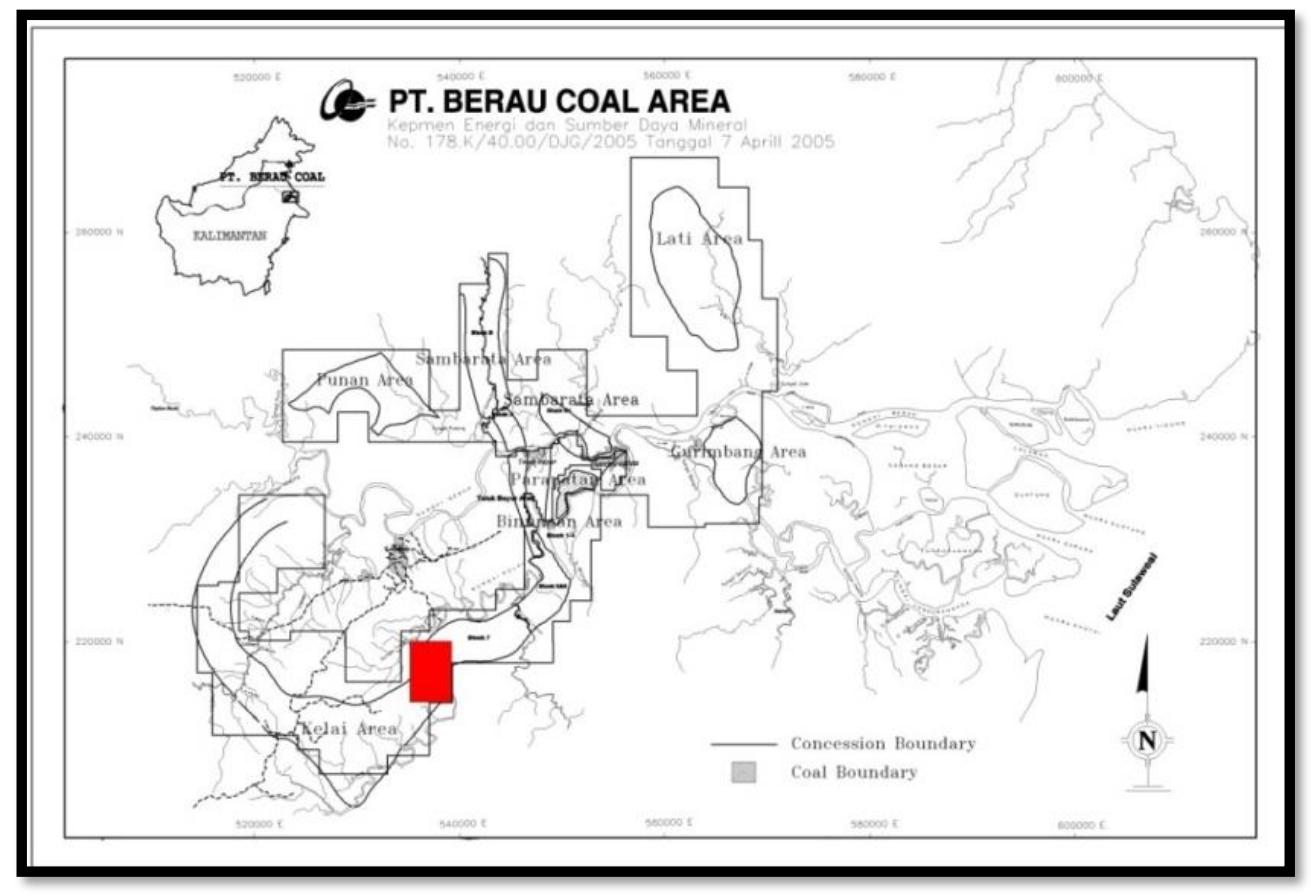

Gambar 1. Lokasi penelitian di daerah Binungan (ditunjukan oleh kotak warna merah), Wilayah konsesi PT Berau Coal.

\section{GEOLOGI REGIONAL}

Secara fisiografis daerah telitian termasuk dalam Sub-Cekungan Berau dari Cekungan Tarakan. Cekungan Tarakan berupa depresi berbentuk busur yang terbuka ke arah timur atau ke arah Selat Makasar atau Laut Sulawesi yang merupakan cekungan paling utara di Kalimantan, yang memanjang dari utara dibatasi oleh zona subduksi di Semenanjung Samporna, dan dibagian barat dibatasi oleh lapisan sedimen Pra Tersier Tinggian Sekatak sedangkan di bagian selatan dibatasi Pegunungan Schwaner dan tinggian Mangkalihat.

Cekungan Tarakan terbentuk bersamaan dengan pembentukan Laut Sulawesi yang disebabkan oleh rifting Sulawesi Utara dan Barat dari Kalimantan Timur (Hamilton, 1979). Peregangan (extension) dan penurunan (subsidence) dimulai Eosen Tengah sampai Akhir dan berhenti pada akhir Miosen Awal. Tektonik Cekungan Tarakan menjadi lebih stabil mulai Miosen Tengah Atas sampai Pliosen dengan pengendapan sedimen deltaik yang berasal dari sebelah barat melalui beberapa sistem drainase. Fase tektonik terakhir adalah kompresi yang dihasilkan dari kolisi lempeng Filipina dengan Borneo atau reaktifisasi dari pegerakan transform sepanjang wrench fault yang memotong Selat Makasar mulai Pliosen Atas dan berlanjut sampai saat ini. Transgresi selama periode ini menghasilkan pembentukan 
busur-busur (arches) Sebatik, Ahus, Bunyu, Tarakan dan Latih.

Struktur geologi regional yang ada di sekitar Berau berupa lipatan, sesar normal, sesar geser, dan kelurusan menunjukan arah utama baratlaut - tenggara dan baratdaya-timurlaut. Di Cekungan Tarakan terdapat 3 sinistral wrench fault yang saling sejajar dan berarah baratlauttenggara, yakni Sesar Semporna, Sesar Maratua dan Sesar Mangkalihat Peninsula.

Secara regional daerah penelitian termasuk dalam sub cekungan Berau yang terdiri dari batuan sedimen, batuan gunungapi dan batuan beku dengan kisaran umur dari Tersier sampai Kuarter, dengan urutan suksesi vertikal dari tua ke muda adalah Formasi Sembakung, Formasi Seilor, Formasi Tabalar, Formasi Birang, Formasi Latih, Formasi Labanan (Domaring), Formasi Sinjin (Sajau) dan endapan alluvial (Situmorang dan Burhan, 1995).

Batubara terbentuk dari sisa-sisa tumbuhan yang sudah mati dengan komposisi utama terdiri dari cellulose atau senyawa organik (Sukandarrumidi, 2006). Menurut Horne dkk. (1978), lingkungan pengendapan batubara dapat dibagi atas:

a. Lingkungan barrier dan back-barrier

b. Lingkungan lower delta plain

c. Lingkungan upper delta plain-fluvial

d. Lingkungan trantitional lower delta plain

\section{METODOLOGI}

Penelitian ini dilakukan dengan metoda pengambilan data langsung dari lapangan dengan cara pengamatan singkapan dan pengamatan inti bor yang dibantu dengan peralatan logigng geofisika. Analisis lingkungan pengendapan dan fasies batubara serta Penghitungan sumberdaya batubara.

\section{- Logging Geofisika}

Geofisika Well Logging merupakan suatu metode geofisika yang dapat memberikan informasi bawah permukaan yang meliputi karakteristik litologi, ketebalan lapisan, kandungan fluida, korelasi struktur, dan kontinuitas batuan dari lubang bor.

BULLETIN OF GEOLOGY, VOL. 3, NO. 1, 2019

DOI: 10.5614/bull.geol.2019.3.1.1

\section{- Gamma Ray}

Prinsip Log Gamma Ray adalah suatu rekaman tingkat radioaktivitas alami yang terjadi karena 3 unsur, uranium (U), thorium (Th) dan potassium (K) yang ada pada batuan (Harsono, 1997).

\section{- Density Log}

Logging densitas dilakukan untuk mengukur densitas batuan disepanjang lubang bor. Prinsip kerja alatnya adalah dengan emisi sumber radioaktif. Semakin padat batuan semakin sulit sinar radioaktif tersebut teremisi dan semakin sedikit emisi radioaktif yang terhitung oleh penerima (counter).

\section{- Caliper Log}

Log ini juga digunakan untuk menentukan kelayakan suatu lapisan batubara pada lokasi tertentu untuk dapat dilakukan pengintian, berdasarkan atas derajat keretakannya yang diperlihatkan oleh garis tengah dari lubang bor yang menembus lapisan tersebut.

\section{- Sumberdaya Batubara}

Sumberdaya batubara (Coal Resources) adalah bagian dari endapan batubara yang diharapkan dapat dimanfaatkan. Data yang digunakan dalam perhitungan hanya berupa data pemboran, maka metode yang digunakan untuk penghitungan sumberdaya daerah penelitian adalah metode Circular (USGS).

\section{HASIL PENELITIAN}

Stratigrafi daerah penelitian Binungan terdiri dari 4 satuan batuan dari yang tertua sampai yang termuda adalah Satuan Batupasir, Satuan Batupasir - Batulempung, Satuan Batupasir Konglomeratan, dan Satuan Endapan Alluvial, dengan penyebaran seperti terlihat 
pada Gambar 2, dengan suksesi vertikal terlihat pada Gambar 3.

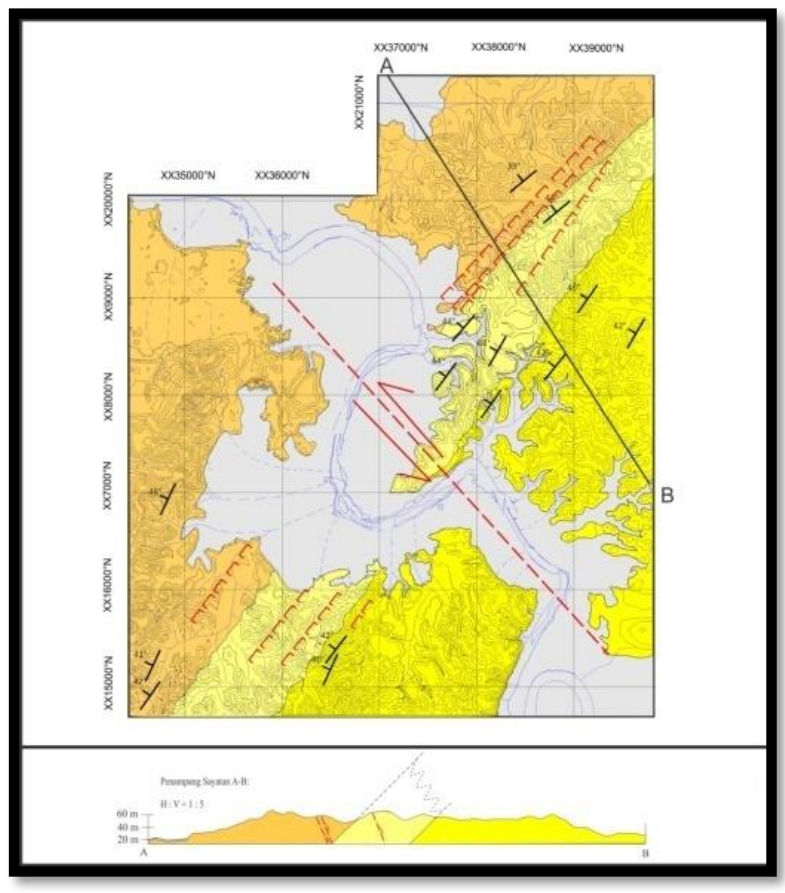

Gambar 2. Peta geologi daerah penelitian dan penampang sayatan A-B (tanpa skala).

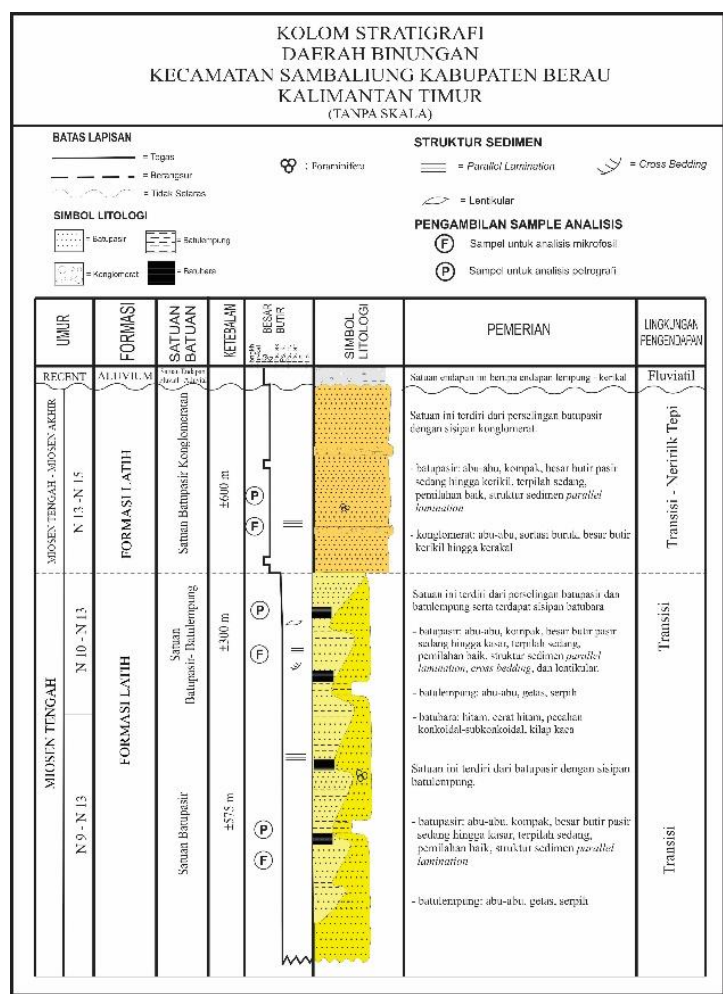

Gambar 3. Kolom stratigrafi daerah penelitian (tanpa skala).
Satuan batuan yang tertua di daerah penelitian adalah satuan batupasir dan perselingan batupasir dengan batu lempung. Kedua satuan ini dikelompokkan masuk dalam Formasi Latih bagian bawah yang berumur Miosen Tengah $\left(\mathrm{N}_{9}-\mathrm{N}_{13}\right)$ diatas kedua satuan ini diendapkan satuan batupasir konglomeratan yang dikelompokkan kedalam Formasi Latih bagian atas yang berumur Miosen Tengah - Miosen Akhir (N ${ }_{13}-\mathrm{N}_{15}$ ). Satuan Batupasir diendapkan di lingkungan Transisi. Selama umur $\mathrm{N}_{10}-\mathrm{N}_{13}$ terjadi regresi lokal yang menyebabkan perubahan fasies yang ditunjukan dengan adanya Satuan Batupasir-Batulempung yang mengandung batubara. Setelah Satuan Batupasir dan Satuan BatupasirBatulempung terbentuk, terendapkan secara selaras Satuan Batupasir Konglomeratan pada umur $\mathrm{N}_{13}-\mathrm{N}_{15}$ (Miosen Tengah-Miosen Akhir). Secara tidak selaras terendapkan Satuan Endapan Alluvial. Satuan ini merupakan satuan paling muda berumur Resen yang berarti pengendapan sedimen pada daerah ini masih berlangsung sampai saat ini.

\section{BATUBARA}

\subsection{Lingkungan Pengedapan}

Lingkungan pengendapan batubara didaerah penelitian didasarkan terhadap analisis fosil, struktur sedimen, ketebalan batubara dan kandungan sulfur pada daerah penelitian. Hasil analisis mikrofosil menunjukkan adanya kemunculan foraminifera bentonik yang merupakan fosil penciri lingkungan laut pada zona transisi. Struktur sedimen yang terdapat didaerah penelitian ialah parallel laminasi, cross bedding, graded bedding dan lentikular. Batubara didaerah tersebut mempunyai karakteristik tebal, sebarannya meluas cenderung memanjang sejajar jurus pengendapan, hadirnya splitting akibat washout oleh channel.

Menurut Ishlah dan Fujiono (2004), data kualitas batubara PT. Berau Coal tahun 2003 mempunyai kandungan total sulfur mencapai $0.08 \%$ yang berarti kandungan sulfurnya 
rendah. (Tabel 5.1.) Berdasarkan analisis fosil, struktur sedimen, ketebalan batubara dan kandungan sulfur tersebut maka lingkungan pengendapan batubara, diinterpretasikan berada di Upper Delta Plain.

Tabel 1. Kualitas Batubara didaerah Binungan.

\begin{tabular}{|c|c|c|c|c|c|c|c|c|c|c|}
\hline \multirow{2}{*}{ Sem } & \multicolumn{10}{|c|}{$\overline{Q U L L T Y}$} \\
\hline & $T M$ & M & $\operatorname{Ash}(18)$ & WM & $\mathrm{FC}$ & $\mathrm{TS}(18)$ & $C V /(18)$ & $\mathrm{N} 22 \mathrm{O}$ & AFI. D & AFT.F \\
\hline$\sqrt{\operatorname{logta}(a)}$ & \begin{tabular}{ll|l}
17.10 \\
\end{tabular} & & 431 & & & 0.76 & 5626 & 183 & 1,160 & \\
\hline Actual (b) & 1780 & & 522 & & & 0.79 & 5596 & 170 & 1,184 & \\
\hline Dftert (0:a) & 070 & & 0.91 & $\overline{7}$ & . & 0003 & (41) & 10.13 & 4 & \\
\hline 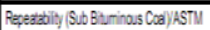 & 0.39 & & 0.34 & & & 0.08 & 27 & 0.11 & 30 & \\
\hline
\end{tabular}

\subsection{Korelasi Batubara}

Pada daerah penelitian, korelasi lapisan batubara yang dilakukan adalah korelasi bawah permukaan menurut kemiripan litologi dari karakteristik fisik masing-masing lapisan batubara berdasarkan gamma ray, long density dan short density. Korelasi yang dilakukan menggunakan korelasi struktur dengan menggunakan data ketinggian titik bor, kedalaman lubang bor dan datum sebagai batas ketinggian.

Pembuatan penampang korelasi titik bor merupakan salah satu tahap dalam pengolahan data dengan tujuan untuk mengetahui kondisi lapisan batubara bawah permukaan. Korelasi pada daerah penelitian dilakukan dengan menarik garis penampang searah dip sebanyak 5 buah (Gambar 4).

Jumlah titik bor pada garis penampang A-B sebanyak 16 buah, pada garis penampang C-D sebanyak 15 buah, pada garis penampang E-F sebanyak 22 buah, pada garis penampang G-H sebanyak 27 buah, pada garis penampang I-J sebanyak 28 buah. Jumlah seluruh titik bor di daerah penelitian ialah 108 buah.

Pada Gambar 5, 6 dan 7 merupakan salah satu contoh korelasi batubara penampang E-F searah kemiringan lapisan batuan, dititik bor Y-06-145 dan titik bor Y-06-96 mempunyai karakterisitik lapisan batubara yang sama, maka dengan karakterisitik yang sama tersebut ditarik garis korelasi dan dinamakan seam $\mathrm{C} 1$ dan seam $\mathrm{B}$.
Dari hasil korelasi tersebut didapatkan bahwa lapisan batubara dari garis penampang E-F hingga ke garis penampang I-J yang dipisahkan oleh sungai besar Kelay ialah lapisan batubara menerus. Lapisan batubara yang menerus dari bagian timur laut hingga barat daya ialah sebanyak 21 lapisan batubara. 


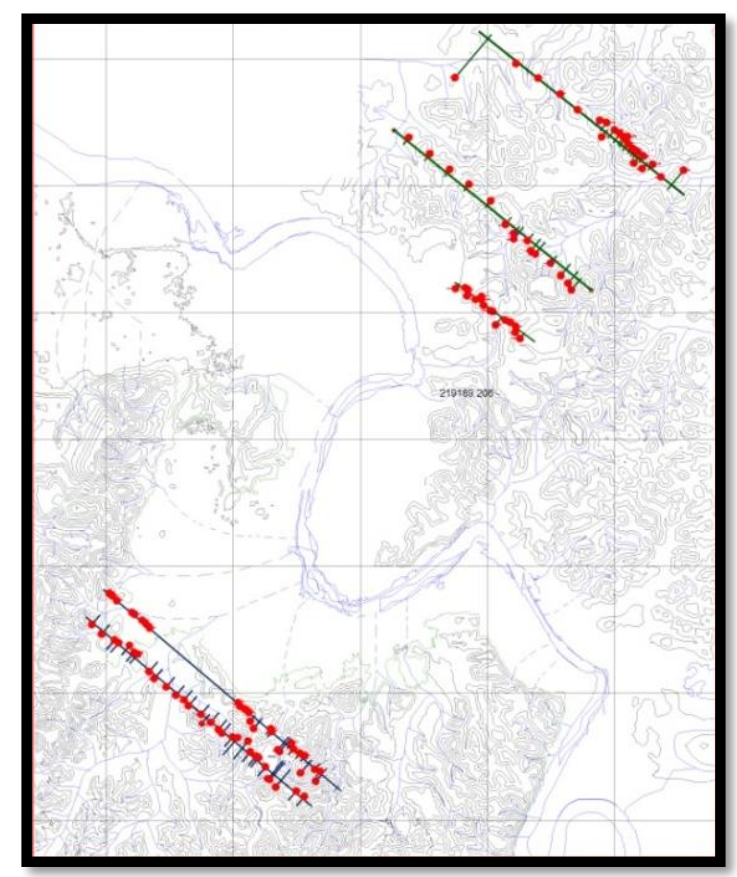

Gambar 4. Peta persebaran titik bor (tanpa skala).

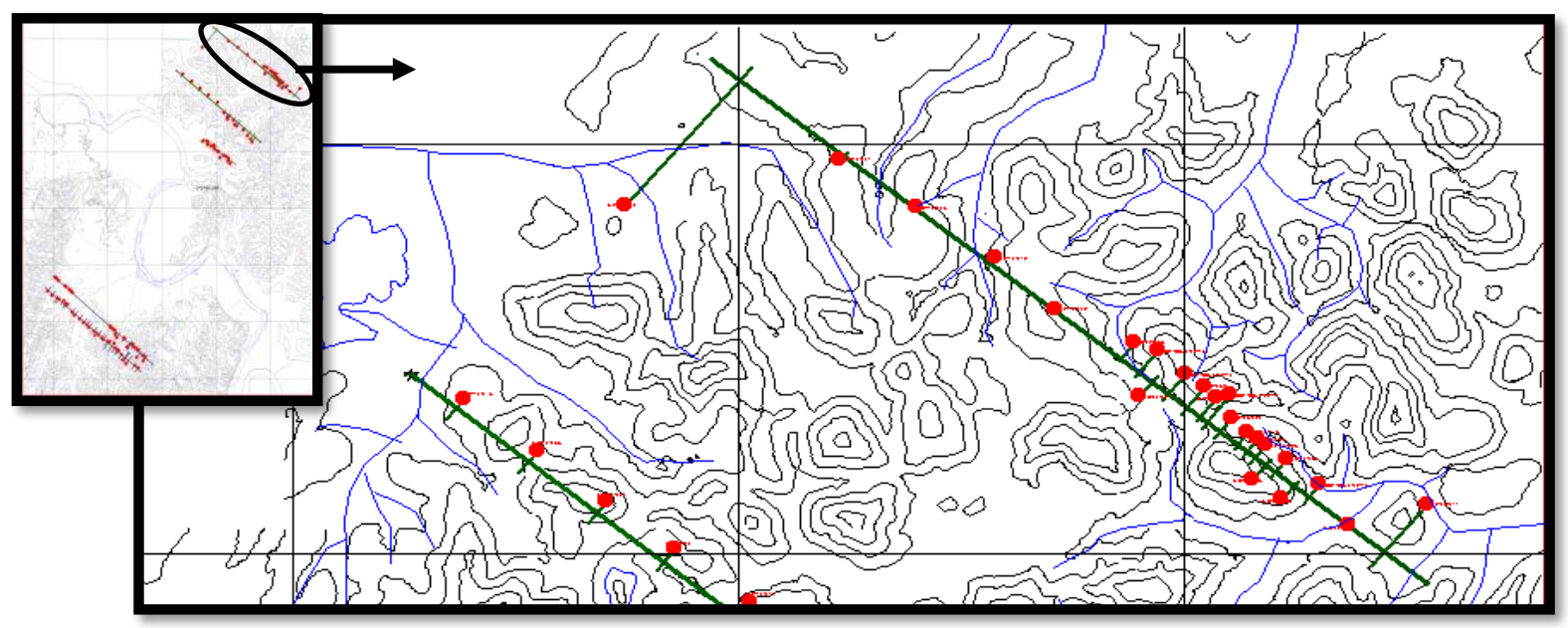

Gambar 5. Garis penampang E-F pada peta kontur (tanpa skala).

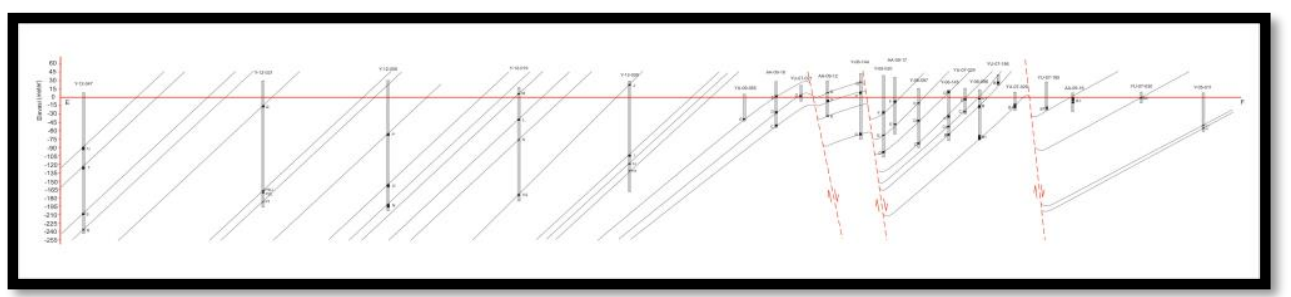

Gambar 6. Korelasi lapisan batubara penampang E-F (tanpa skala). 

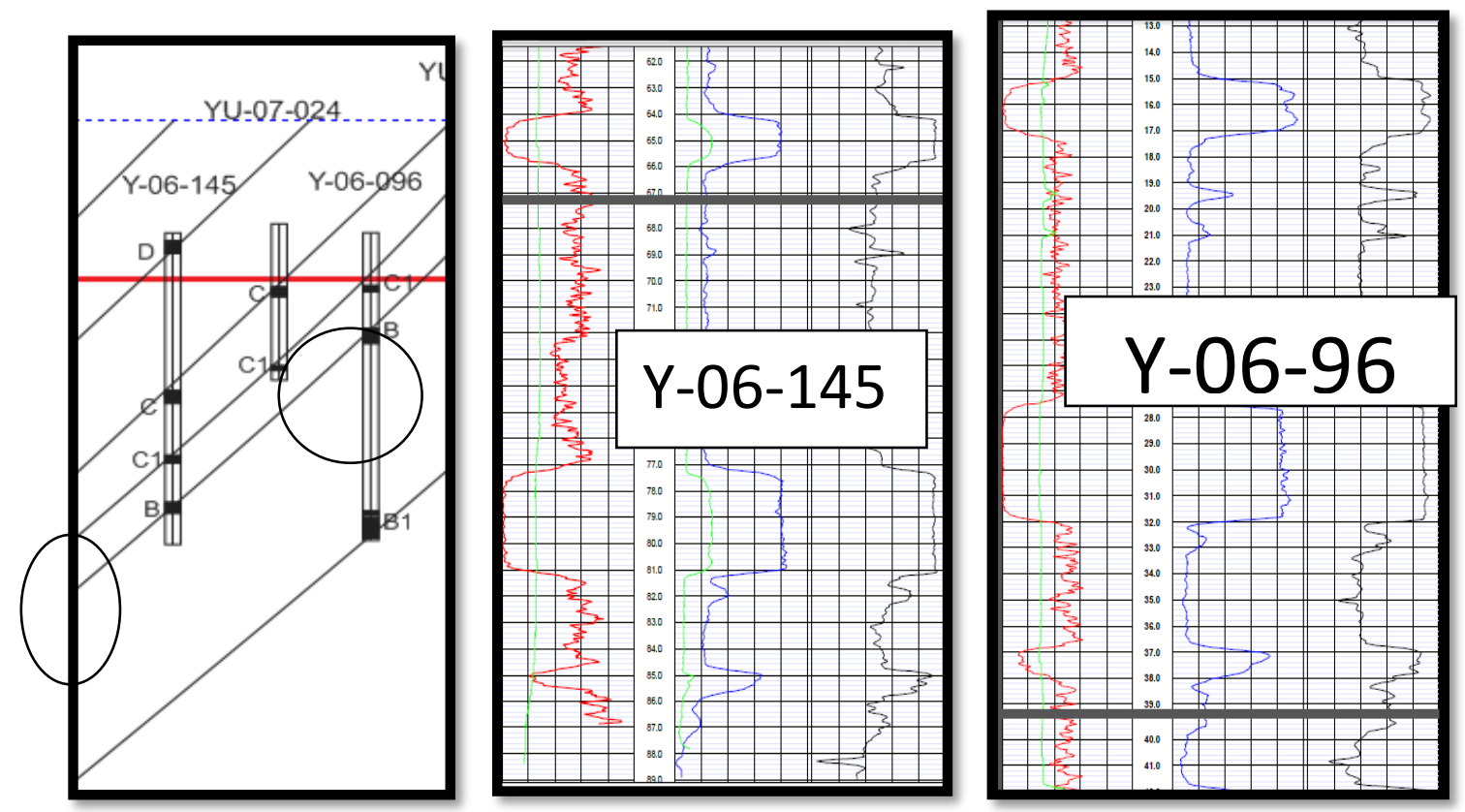

Gambar 7. Salah satu contoh karakteristik lapisan batubara dipenampang E-F (tanpa skala).

\subsection{Sumberdaya Batubara}

Persyaratan batas minimal ketebalan lapisan batubara yang dihitung menurut Standar Nasional Indonesia ialah 0.40 meter dan dengan kedalaman hingga 100 meter. Sumberdaya terukur (radius 0-400 meter) pada daerah penelitian yaitu 507,622,707.17 ton. Sumberdaya tertunjuk (radius 400-1200 meter) pada daerah penelitian yaitu $1,279,821,110.78$ ton.

\section{KESIMPULAN}

Berdasarkan hasil penelitian yang dilakukan didaerah Binungan dan sekitarnya, dapat diambil kesimpulan mengenai daerah penelitian sebagai berikut:

1. Satuan batuan pada daerah penelitian dibagi menjadi 4 satuan batuan, dimana satuan batuan dari tua ke muda adalah Satuan Batupasir, Satuan Batupasir-Batulempung, Satuan Batupasir Konglomeratan dan Satuan Endapan Alluvial.

2. Korelasi lapisan batubara dilakukan dari karakteristik fisik masing-masing lapisan batubara berdasarkan data $e$-log dengan menggunakan gamma ray, long density dan short density. Lapisan batubara diketahui menerus disepanjang barat daya hingga timur laut daerah penelitian.
3. Jumlah lapisan batubara yang berada di daerah Binungan ialah sebanyak 43 lapisan dengan 23 lapisan batubara yang menerus dan 20 lapisan batubara yang tidak menerus.

4. Sumberdaya terukur batubara pada daerah penelitian yaitu sebesar $507,622,707.17$ ton dan sumberdaya tertunjuk yaitu sebesar 1,279,821,110.78 ton, dengan persyaratan batas minimal ketebalan lapisan batubara yang dihitung menurut Standar Nasional Indonesia ialah 0.40 meter dan dengan kedalaman hingga 100 meter.

\section{DAFTAR PUSTAKA}

Achmad, Z. dan Samuel, L. 1984. Stratigraphy and Depositional Cycles in the N.E. Kalimantan Basin. IPA 13th Annual Convention Proceeding.

Andu, R. 1987. Kamus Geologi. Semarang: Dahara Prize.

Anonim. 1995. Petroleum Geology of Indonesian Basins (Volume V Tarakan Basin Northeast Kalimantan).

Anonim. 1998. SNI - Klasifikasi Sumberdaya dan Cadangan Batubara. Badan Standarisasi Nasional - BSN. 
Bandy, O. L. 1967. Benthic Foraminifera as Environmental Indices. In Bandy, O.L., Ingle, J.C. et al., (eds.), Paleoecology. American Geological Institute Short Course Lecture Notes, 1-29.

Blow, W.H. dan Banner, F.T. 1966. The Morphology, Taxonomy and Biostratigraphy, Micropaleontology Vol. 12(3).

Hamilton, W. 1979. Tectonic of Indonesian Region. US: Geological Survey, Professional Paper 1078.

Harsono, Adi. 1997. Evaluasi Formasi dan Aplikasi Log. Jakarta: Schlumberger Oilfield Services.

Horne, J. C., Ferm, J. C., Caruccio, F. T., and Baganz, B. P. 1978. Depositional Models in Coal Exploration and Mine Planning in Appalachian Region. American Association of Petroleum Geologists Bulletin, v. 62, p. 2379-2411.

Howard, Arthur David. 1967. Drainage Analysis in Geologic Interpretation: A Summation. The American Association of Petroleum Geologists Bulletin, Vol. 51, No. 11: 2246-2259.

Ishlah dan Fujiono. 2004. Evaluasi Konservasi Sumberdaya Batubara disekitar Tanjung Redep Kabupaten Berau Kalimantan Timur. Kolokium Hasil Lapangan.

Pettijohn, F.J. 1975. Sedimentary Rock Third Edition. Harper \& Row Publishers, New York-Evanston-San Fransisco-London.

Situmorang dan Burhan. 1995. Peta Geologi Lembar Tanjung Redeb, Kalimantan. Bandung: Pusat Penelitian dan Pengembangan Geologi

Sukandarrumidi. 2006. Batubara dan Pemanfaatannya. Yogyakarta: Gadjah Mada University Press.

Sukandarrumidi. 2008. Batubara dan Gambut. Yogyakarta: Gadjah Mada University Press.

Sukardi, B., Djamal, S., Supriatna dan Santosa, 1995. Peta Geologi Lembar Muaralasan, Kalimantan. Bandung: Pusat Penelitian dan Pengembangan Geologi.
Wahab, Abdul, 1996. Sandi Stratigrafi Indonesia. Jakarta: IAGI.

Wight, A.W.R., Hare, L.H., dan Reynolds, J.R. 1993. Tarakan Basin, NE Kalimantan, Indonesia: a Century of Exploration and Future Potential. Geological Society of Malaysia, Bulletin 33.

Wood, G. H. Jr., Kehn. T. M. Carter, M., D., and Culbersion, W.C. 1983. Coal Resources Classification System of U.S. Geological Survey. U.S Geological Survey Circular 89. 65 p Bulletin. 